\title{
The Role of Human Resources Management in Corporate Social Responsibility at PT Kutai Timber Indonesia (PT. KTI)
}

\section{Gilang Prawira Sumantri and Sopiah}

Universitas Negeri Malang

\section{Abstract}

The existence of companies earning profits through extracting of natural resources from community's/inhabitant's environment has contributed to the growing awareness about the concept of Corporate Social Responsibility (CSR). Aspects of CSR related to employee participation require support from human resource management (HRM). Although research linking the role of HRM and CSR has seen a significant increase, but there is still no comprehensive approach that examines these two concepts jointly. This study aims to consider the structure of CSR-HRM at PT Kutai Timber Indonesia (PT KTI), the role of HRM in the development and implementation of CSR, and the

Corresponding Author: Gilang Prawira Sumantri sopiah.fe@um.ac.id

Received: 2 May 2020 Accepted: 4 July 2020 Published: 14 July 2020

Publishing services provided by Knowledge E

(c) Gilang Prawira Sumantri and Sopiah. This article is distributed under the terms of the Commons Attribution License, which permits unrestricted use and redistribution provided that the original author and source are credited.

Selection and Peer-review under the responsibility of the ICIEHI Conference Committee. contribution of HRM in corporate sustainability through CSR at PT KTI. The study used a qualitative approach to the type of case study research. Data collection techniques included in-depth interviews, observation, and documentation. Data analysis in this study was carried out in three stages, namely data reduction, data presentation, and final conclusion. The validity test of data is used the method of source triangulation and technical triangulation. The research findings conclude that the understanding of CSR adopted by PT KTI was still focused on the external dimension, so the structure of PT KTI's CSR-HRM was limited to administrative relations. HRM in the HRD Department of PT KTI does not have a strategic role related to the development of CSR, but has an administrative role related to employee licensing in implementing CSR. PT KTI's HRD department contributes to corporate sustainability through HRM core tasks. The limitation of this study is its limitation to be generalized to other sites/objects. The sound generalization could be applied only to objects/sites that have similar or similar characteristics.

Keywords: CSR, the role of HRM, corporate sustainability, PT KTI.

\section{Introduction}

Business companies or organizations cannot be separated from the environment in which the organization is located. The existence of companies earning profits through the extracting natural resources from the community's environment creates the growing awareness about the concept of Corporate Social Responsibility (CSR). According to 
through wise business practices and corporate's resource contributions. This definition emphasizes on CSR activities which are solely voluntary company commitments to contribute towards the welfare of the community and are not a business activity obligated by law or legislation.

In Indonesia, the implementation of CSR is actually regulated in the Law of PT (Perseroan Terbatas/limited company) No. 40 of 2007 article 74 which containing the obligation for companies to implement CSR in the community. The presence of legislation governing the obligation to carry out CSR in Indonesia has invited polemics. However, as long as this is not misused to cover harmful corporate practices, this regulation can be an advantage for the community, especially those living around the company. This regulation also makes CSR more intensively implemented, especially by large and multinational companies operating in Indonesia.

In carrying out CSR activities, there are no certain standards or practices that are considered the best. Every company has unique characteristics and situations that influence how they perceive social responsibility (Susanto, 2009: 48). In other words, companies have their own ways in the CSR strategy depending on the operational conditions that occur in the company. Solihin (2009: 145-146) mentions that there are main conditions that will ensure the implementation of CSR programs properly. These conditions include the approval and support of the involved parties, clear coordination between parties, and good management of the program from the company.

Good management of CSR is related to the success of the company in integrating CSR policies within the organization. Therefore, CSR should be used as an important need internalized in management systems and business practices and organizational culture (Lako, 2011: 6). Internalization of CSR values is not an easy job, as stated by Dunphy \& Benn (in Sarvaiya et al., 2016) stating that the development and implementation of CSR strategies are related to considerable changes in the organization.

Bolton et al. (2011) stated in their study that the process of developing CSR relates to employee dimensions, where employees have an important role as internal stakeholders in shaping and maintaining a corporate identity as a "good corporate". The aspects of CSR related to employee participation will require support from the HR department. Strandberg (2009:12) shows that HRM is a strategic partner in the organization and thus can help driving the formulation of CSR strategies. The role of HRM in implementing CSR strategies is widely discussed as a majority in CSR initiatives, such as community involvement and environmental projects, requiring direct or indirect participation from employees (Mirvis, 2012:102). 
In practice, many companies have established their own CSR departments or placed CSR responsibilities in other departments, so the preparation of CSR strategies is separated from the HR department. Therefore, there is overlapping of the domains of CSR and HRM, which results in political struggles around functional areas (Gond et al., 2011:124). The relationship between the CSR department and HR in sharing responsibilities regarding the development and implementation of CSR is rarely investigated. In this situation, how HRM can offer strategic or administrative inputs is still not clearly known.

As a company operating in the industry extracting natural resources, PT Kutai Timber Indonesia (PT KTI) has the obligation to implement CSR in accordance with the Law of PT (Perseroan Terbatas/limited company) No. 40 of 2007 article 74. The CSR program carried out by PT KTI together with its parent company, Sumitomo Group, has actually been implemented even before the enforcement of regulations requiring the implementation of CSR for each company. One example of the implementation of CSR by Sumitomo Group and PT KTI is the rehabilitation of Way Kambas National Park in Lampung Province which began in 1999 and ended in 2004 with a total area of 360 hectares.

PT KTI apprehends CSR as a form of strategy in achieving environmental sustainability and corporate sustainability. PT KTI upholds environmental sustainability, surely not without a cause, but because PT KTI is an industry that uses natural resources to generate profits. Therefore, by upholding environmental sustainability, PT KTI can also indirectly maintain the sustainability of its business in the wood utilization industry.

Shortly, selecting PT. KAl is based on several reason: 1) PT KTI is a company engaged in the industry of natural resource utilization so that CSR activities should have become an internally integrated culture for the company; 2) PT KTI prioritizes the company's sustainability through CSR programs in social and environmental fields where planning and implementation requires a direct role of employee involvement through HRM functions available within the company; 3) CSR management in PT KTI is handed by the System Management department, separated from the HRM function in the Human Resource Development department so that it is necessary to clearly identify the role of each department in CSR strategy and implementation.

This study raises three main focuses that need to be explored in this study, namely: (1) the structure of CSR-HRM in PT KTI in general; (2) the role of HRM in the Department of Human Resource Development (HRD) of PT KTI in the development and implementation of CSR; and (3) the contribution of HRM in upholding corporate sustainability through CSR programs at PT KTI. The novelty of this study is developing the existing concept of 
corporate social responsibility literature, based on practices, and relating it to the role of human resource management with qualitative studies.

\section{Literature Review}

\subsection{Dimensions of CSR}

The European Commission (2001) divides the dimensions of CSR based on a stakeholder approach. Freeman (in Kartini, 2009) explains the stakeholders (stakeholders) in this case are people or groups who can influence or be affected by various decisions, policies, and company operations. This stakeholder approach gives rise to two CSR categories, namely internal CSR and external CSR. The internal dimension of CSR is associated with internal stakeholders, namely employees. Thus, this dimension relates to practices related to HRM, specifically health and safety, employee welfare, gender equality and diversity (European Commission, 2001). As for the external dimension of CSR, it covers a variety of practices for external stakeholders. Welford (2005) identified various elements or themes of external CSR, which included employment aspects related to suppliers, global environmental standards, protection of human rights, community or community development, and fair-trade policies. Furthermore, The Jakarta Consulting Group (in Susanto, 2009) explained that social responsibility must be directed both inside (internally) and outside (externally) of the company. Internal responsibility is directed at shareholders in the form of profitability and growth and is also directed at employees. Only with hard work, contributions and sacrifices, they can carry out various activities and achieve success. Outward corporate (external) corporate social responsibility is related to the company's role as a taxpayer and employer, agent which is improving the welfare and competence of the community, and protecting the environment for the benefit of future generations.

\subsection{Role of HRM regarding CSR}

Strandberg (2009) argues that HRM cannot be excluded from the formulation of CSR policies and strategies. HRM has a key position in playing an instrumental role to help the organization achieve its goals of being a socially-responsible company. CSR strategies and policies of a company will always need the support and participation of its employees, so through this HRM's function, support and participation of employees can be obtained. Furthermore, Strandberg (2009) shows that HR is a strategic partner 
in the organization and thus, can help encourage the formulation of CSR strategies. HR can initiate conversations with various stakeholders to support decision making by simultaneously developing CSR policies (Fenwick \& Bierema, 2008). HR can also review the necessary code of ethics and ethics, and thus HR can take a leading role in decision-making related to CSR (Lam \& Khare, 2010: 13). HRM which can be seen as a strategic key of the organization, can adjust the development of CSR in accordance with the nature and culture of the company's organization.

Regarding CSR implementation, HRM still has vital role. The CSR implementation process itself consists of various stages, such as involving CSR participants, communicating and internalizing CSR in organizations, and monitoring CSR performance (Sarvaiya, 2014). Implementation of CSR strategies often requires changes in organizational structure, communicating with stakeholders, and instilling CSR in organizational strategies, processes and practices (Cannon in Sarvaiya, 2014). Some HR literatures recognize that the strategic role of $\mathrm{HR}$ is more probable to implement strategies and translate those strategies into HR practices. Referring to the role of HR in CSR, Yang et al. (2013) shows that HRM is more likely to be responsible for implementing their organization's CSR strategy rather than directly involved in its development. Because implementing CSR strategies requires the integration of ethical values and standards throughout the organization and its people, the key role of HR is an important requirement in developing and supporting CSR culture into the organization. Sarvaiya (2014) mentions four key reasons that make HRM possible to play a role in implementing CSR strategies. Firstly, HRM can contribute to raise employee awareness about CSR strategies. For example, the HRM function can initiate dialogue with employees through training and orientation programs to ensure a uniform understanding of the company's CSR. Secondly, most CSR-related activities, such as social community development projects and environmental initiatives, require the involvement of employees in the process. Third, HRM can offer organizational change management related to CSR. HRM can improve employee performance and behavior by offering training and job descriptions related to CSR. Fourth, HRM can directly contribute to the internal dimensions of CSR. This is because activities related to work balance, employee welfare, and internal organizational practices are a natural scope of HRM. 


\section{Research Methodology}

This research tries to explore the role of HRM in the Human Resource Development (HRD) department at PT KTI in the strategy and implementation of CSR through the perspective of the company's managerial line. The research approach used is descriptive qualitative, which the researcher collects data in the form of descriptions of sentences or written words or oral and not in the form of numbers.

The type of research used is a case study, where this study tries to find scientific result by studying-in-depth a program, event, process, and activity in some period of time. This research is expected to reveal the facts related to the role of human resource management (HRM) in CSR at PT Kutai Timber Indonesia (PT KTI).

The researcher is a key instrument of research that plays a direct role in setting the focus of research, selecting informants as a source of data, collecting data, processing and analyzing data, and making conclusions on the basis of research findings. The presence of researchers at the research location determines the credibility and validity of the data. The research was conducted at PT Kutai Timber Indonesia. This study uses primary data sources and secondary data. Primary data is obtained through the results of in-depth interviews with informants related to the scope of the research problem. The selected informants were representatives of staff from each department of Human Resource Development and System Management. While secondary data in this study are used as supporting components of research. The data is obtained through official company archive documentations in the form of CSR program reports, organizational structures, and other official archives related to research topics. Data analysis in this study was carried out through three stages, namely data reduction, data presentation, and final conclusion. The validity test of data used the method of source triangulation and technical triangulation. For confidential reason, all the name of respondents are in initial form.

\section{Research Result}

The results of this study are divided into four parts:

\subsection{Structure and Practice of Corporate CSR-HRM}

Discussing the structure and practice of corporate CSR-HRM is useful in order to understand the company's contextual factors related to the role of HRM in CSR. These factors 
include the dimensions of the CSR application, organizational structure, managerial relations of HRM with CSR, and so on. As explained by Sarvaiya et al (2016), these factors are useful so that there is no "one-size-fits-all" justification which the conclusions are applied regardless of the contextual factors that occur in a company.

CSR at PT Kutai Timber Indonesia (PT KTI) is still focused on external initiatives. The researcher found that $\mathrm{PT} \mathrm{KTI}$, which is engaged in the extraction of natural resources as its business focus, has CSR priorities in environmental aspects and community empowerment.

CSR is the responsibility of the company, especially to the surrounding community. From PT KTI's point of view, CSR is divided into two areas based on their implementation, namely range 1 and range 2. (AS, Department of Human Resources).

Almost all of the informants in this study expressed their understanding of PT KTI's CSR as a responsibility to the surrounding community. The statement on this item is also strengthened by the legal basis that applies in Indonesia.

This CSR for PT KTI companies is an obligation that has been regulated by law to be implemented, especially in the community around the company. (AS, Department of Human Resources).

This understanding of CSR is in accordance with Kotler and Lee's statement (in Solihin, 2011:5) which views CSR as a form of commitment to improve community welfare through wise business practices and corporate's resource contributions. In this definition, the focus of CSR lies with external stakeholders with the main goal of CSR as a form of improving community welfare.

Related to the relationship between CSR and HRM in the organization, the informants in this study revealed that HRM only has administrative relations regarding permits to use personnel outside the company in the context of CSR.

HRM is here since the enactment of the new organizational structure. It does not manage CSR anymore, Sir. The relationship is only administrative, it is only related to employee involvement. (S, Department of Human Resources)

The implementation of PT KTI's CSR strategy that focuses on the external dimension became the basis for PT KTI to establish CSR management responsibilities in the System Management (SM) department. This was formalized through the application of the organizational structure of PT KTI's HR \& GA division which has prevailed per January 
2018. With the implementation of this organizational structure, the position between CSR and HRM became clearer where the HRD Department no longer had a vital role in CSR, especially those related to preparation of CSR strategies. The responsibility for managing CSR is placed in other departments that are outside the scope of HRM.

\title{
4.2. The Role of HRM in CSR Development
}

The development of CSR strategies relates to defining CSR values and objectives, formulating strategies in the field, and designing various CSR projects and initiatives (Sarvaiya et al, 2016). In the context of developing this CSR, Strandberg (2009:5) states that human resource management has an important role that cannot be avoided because HRM is a key instrument that manages employee involvement in CSR.

Field facts at PT KTI itself show that strategic development of CSR is within the Department of System Management (SM) work area that is separate from the HRM scope. This condition makes the HRM function in the Human Resource Development (HRD) department not having a strategic role in developing CSR policies.

In development, I don't think there is any. Because for those who compiled the CSR work plan in the organizational structure that had been running as of last January it was the area of management systems. And for the strategic planning not with the HRD, but with the general affair. (AS, Department of $S M)$.

The statement also revealed that in the strategic planning of CSR, the Department of SM does not cooperate with the HRD Department, but with the General Affair (GA) department CSR policies that focus on the company's external environment also directly make the HRM function not too necessary in the preparation of CSR strategies PT KTI.

\begin{abstract}
About development, nothing. That's all the area of system management and general affairs. HRD is here to treat employees only, employee welfare, including administrative matters with outside parties. (RS, Department of Human Resources).
\end{abstract}

\subsection{The Role of HRM in CSR Implementation}

Referring to the research conducted by Sarvaiya et al (2016), HRM has a considerable role in the implementation of CSR. This is related to the credibility of HRM in promoting 
employee participation and providing administrative support in the implementation of CSR.

Although the contribution of HRM to CSR at PT KTI cannot yet be considered as having strategic input, the HR function of PT KTI has an important position as an administrative support provider, especially regarding permits for employee involvement in CSR activities. In this case, the HRM function plays an important role in supporting the implementation of the CSR strategy.

For the implementation of CSR, HRD only plays a role in giving permission for contributions to employees, who are appointed directly by the relevant department head (AS, Department of SM)

Regarding the promotion of employee participation, the KTI PT HR function only serves to give an appeal to employees to be able to attend to the success of the CSR program. Overall, the selection of participants and responsibility for CSR participants is still within the working area of the System Management department.

Only licensing, so to give administrative permission to employees assigned to participate in CSR activities during working hours. For outside working hours, such as CSR activities, we also encourage employees to attend. (RS, Department of HRD)

Garavan et al. (2010) stated that HRM has important synergies with CSR, but ideally HRM has a role in integrating CSR principles into the organization. Regarding the implementation of PT KTI which is focused externally, the integration of CSR principles into the organization still cannot be clearly defined. The internal focus at PT KTI is not mentioned as a form of CSR, but rather on core HRM programs related to the development and improvement of the quality of the workforce.

\subsection{HR Contribution in The Company's Sustainability through CSR}

The CSR at PT KTI has strategic implications with company's sustainability. This is mainly related to sustainability from outside the organization because the main priority of PT KTI's CSR focuses on external dimensions. Through CSR, companies are able to build a positive image in the eyes of the public, both in the area around the company (ring 1), as well as the general public in general (ring 2).

This CSR can be regarded as forming the image of the company itself. From this CSR, it can be seen how much we care about the surrounding community. If our CSR is good, our company can last long. (AS, Department of SM) 
Sustainability which is an organizational goal can be obtained through CSR practices supported by the integration of CSR principles into the organization. In the context of PT KTI, the structure of CSR that is in a different scope from HRM makes it impossible for opportunities to support corporate sustainability through CSR programs.

However, HRM at PT KTI is still involved in supporting sustainability through the employee recruitment process around the company. This process is one of the core functions of HRM which indirectly has strategic implications for corporate sustainability. This process can also be said as a form of corporate responsibility that is able to provide sustainable welfare for the surrounding community.

I think that for the sustainability of CSR companies it will not have too much impact. It is precisely the most impacted in the HRD department, that recruitment bro. So we prioritize the people of Probolinggo themselves for recruitment. (AS, Department of SM).

The role of the employee recruitment process around the company also has strategic implications for corporate sustainability. This process can also be said as a form of corporate responsibility that is able to provide sustainable welfare for the surrounding community.

We maintain this sustainability through a positive image in the eyes of the community, right, we have recruited, so we take it from the surrounding community, even though it is not CSR, but this recruitment also contributes to the welfare of the community around the company. (SC, Department of $H R D)$.

One way to support company sustainability is through the integration of CSR into HRM practices. Cohen et al. (2012: 2-3) explained that HRM can take a leading role in developing and implementing a company's sustainability strategy through well-internalized CSR programs into corporate organizations.

The integration of CSR into the company's MSDM practices is realized through a form of energy-saving culture that is invested in all levels of employees at PT KTI in the concept of energy conservation.

We exemplify energy conservation, so conservation is not only outward, but also inside. From this, we give appeals to employees to save even more on the use of electricity and water through the same poster of the pamphlets. (AS, Department of SM) 
Besides in the form of appeals, CSR elements are also included in employee training and orientation programs. In addition to in the form of appeals, CSR principles are also included in employee training and orientation programs.

We have employee training, employee orientation, we enter the elements of CSR. Save on water and electricity usage, use safety devices while working. (RS, Department of HRD)

The role of HRM in PT KTI's HRD Department regarding company sustainability in general cannot be categorized into CSR practices. The HRD department has a good role in maintaining the sustainability of the company through the core tasks of the HRM function, which include the recruitment of employees from the surrounding community, employee training and orientation, and other internal activities. In this way, the HRD Department has contributed significantly to the sustainability of the company and at the same time, helped maintain the welfare of the community around the company

\section{Discussion}

Based on the results of the study, it can be said that the understanding of CSR adopted by PT KTI still focuses on the external dimension, where CSR is seen as a form of corporate responsibility towards external stakeholders, especially the community and the environment around the company. Regarding the focus of CSR which prioritizes the external dimension, the structure of the relationship between HRM and CSR at PT KTI is limited to administrative relations in the form of giving permission to employees who participate in PT KTI's CSR program.

Determination of CSR management in a department that focuses on the company's external area and outside the scope of HRM does not mean a wrong decision. Sarvaiya (2016), in his research entitled "The Roles of HRM in CSR: Strategic Partnership or Operational Support?" which explored the role of HRM in CSR in 16 large companies in New Zealand, found that companies that use natural resources or create risks for environment, tends to have CSR priorities on the external dimension, especially those related to environmental and community aspects.

HR management in the Human Resource Development (HRD) department of PT KTI does not have a strategic role in developing CSR. This finding supports a number of previous studies, one of them in a study conducted by Fenwick \& Bierema (2008) which shows that HRM does not play a role or even have no relationship at all with the development and CSR initiatives. Sarvaiya et al (2016) also support this finding. Based on 
the results of his research, the contribution of HRM in CSR that focuses on the external dimension cannot be considered as having strategic input. Even in companies that claim to have a core commitment to CSR, HRM has only a relatively limited relationship. This finding is different from several theoretical and empirical reviews which state that HRM cannot be separated from the process of developing a CSR strategy. One of the claims from Strandberg (2009) in the conceptual literature is that the contribution of HRM cannot be avoided in designing a CSR strategy. Archdivili (2013) who argues that HRM can play a major role in sustainability both through individual employee practices and organizational culture and practices.

Some theoretical and empirical reviews argue that HRM has a considerable role in the implementation of CSR, including in terms of management of changes related to CSR, promoting employee participation, and providing administrative support (Sarvaiya et al, 2016). Garavan et al. (2010) stated that HRM has important synergies with CSR, but ideally HRM has a role in integrating CSR principles into the organization. Regarding the implementation of PT KTI which is focused externally, the integration of CSR principles into the organization still cannot be clearly defined. In real conditions, HRM in PT KTI's HRD Department in implementing CSR relatively only has administrative roles related to permit management in CSR contributions.

Stefano et al (2017) in his study, which reviewed 122 international articles related to HRM relations and sustainability, concluded that HRM has a potential role in supporting corporate sustainability through CSR programs. Sustainability which is an organizational goal can be obtained through CSR practices supported by the integration of CSR principles into the organization. In the context of PT KTI, the structure of CSR that is in a different scope from HRM makes it impossible for opportunities to support corporate sustainability through CSR programs. The HRD department has a good role in maintaining the sustainability of the company through the core tasks of the HRM function, which include the recruitment of employees from the surrounding community, employee training and orientation, and other internal activities. Some of the results of previous studies show a greater role for HRM in the sustainability of the company.

\section{Conclusion}

Through this research, it can be concluded that the structure of PT KTI's CSR-HRM focuses on the external dimension. This is because the business sector which is handled by PT KTI is a natural resource utilization business, which is directly related to its impact on the environment and surrounding communities. 
As a result of the focus on implementing this company's CSR, the scope of management or work area regarding CSR is outside the work area of the HRM function in the PT KTI HRD department in the organizational structure. The CSR work area is precisely in the System Management (SM) department, the CSR and Proper section. In the process of planning and developing CSR, the BC department works with the General Affair (GA) department, and not with the HR department. Therefore, the HRM function does not have a strategic role related to the development of CSR at PT KTI.

HRM at PT KTI only has an administrative role in the implementation of corporate CSR, especially in terms of granting permission to contribute to employees. MSDM at $\mathrm{PT} \mathrm{KTI}$ does not have formal integration with $\mathrm{CSR}$, especially in relation to the selection of participants in CSR activities and giving appeals for contributions. HRM at PT KTI contributes to achieving corporate sustainability through the core tasks of HRM, namely the recruitment of employees from the community around the company and the cultivation of CSR values through employee orientation and training.

This research is expected to fill the gap of several theories and empiricists who assume that HRM will always have a key role in CSR because of its relevance to employee participation. That in this case, re-understanding is needed regarding the contextual factors that apply to the company to be able to determine the role of HRM in CSR, whether strategic or not.

\section{Suggestion}

This study suggests that PT KTI can develop formal integration between the functions of CSR and HRM. This can be implemented through representation of HRM representatives in departments that handle CSR or through a formal CSR-HR agenda where the functions of CSR and HRM can work together while developing or implementing a CSR strategy. Through the development of relationships in the structure of the company's CSR-MSDM, the HRM function can improve the skills and expertise of HR in CSR aspects related to the internalization of CSR values into the organization. Therefore CSR can produce a good corporate image from the external side, and simultaneously be able to develop good organizational quality internally.

This study also has a number of limitations, especially related to the period of research that is felt to be lacking and the object of research that only consists of one company. Hence, further studies are recommended to be able to present objects or samples of more than one company with a variety of different business fields. Through this 
method, it is expected to produce more general research findings for the scientific field that discuss the relationship of CSR with HRM.

\section{References}

[1] Ali, A.J. and Al-Owaihan, A. (2008) Islamic Work Ethic: A Cross Cultural Management: An International Journal, vol. 15, issue 1, pp. 5-19, doi.org/ $10.1108 / 13527600810848791$.

[2] Ardichvili, A. (2013). The Role of HRD in CSR, Sustainability, and Ethics: A Relational Model. Human Resource Development Review, vol. 12, issue 4, pp. 456-473, doi.org/10.1177/1534484313478421.

[3] Bolton, S.C., Kim, R.C. and O'Gorman, K.D. (2011). Corporate Social Responsibility as a Dynamic Internal Organizational Process: A Case Study. Journal of Business Ethics, vol. 101, issue 1, pp. 61-74, doi.org/10.1007/ s10551-010-0709-5.

[4] Bučiūnienè, I. and Kazlauskaitè, R. (2012). The Linkage between HRM, CSR And Performance Outcome. Baltic Journal of Management, vol. 7, issue 1, pp. 5-24, https: //doi.org/10.1108/17465261211195856.

[5] Carroll, A. and Buchholtz, A. (2008). Business and Society: Ethics and Stakeholder Management ( $7^{\text {th }}$ Edition). Retrieved from https://epdf.tips/download/business-andsociety-ethics-and-stakeholder-management-7th-edition.html.

[6] Cohen, E., Taylor, S. and Muller-Camen, M. (2012). HRM's Role in Corporate Social and Environmental Sustainability. Retrieved from https://www.shrm.org/hr-today/ trends-and-forecasting/special-reports-and-expert-views/Documents/CorporateSocial-Environmental-Sustainability.pdf.

[7] Dessler, G. (2010). Manajemen Sumber Daya Manusia. Jakarta: Indeks.

[8] European Commission. (2001, July 18). Promoting a European Framework for Corporate Social Responsibility. Retrieved from http://europa.eu/rapid/pressrelease_DOC-01-9_en.pdf.

[9] Fenwick, T. and Bierema, L. (2008). Corporate Social Responsibility: Issues for Human Resource Development Professionals. International Journal of Training and Development, vol. 12, issue 1, pp. 24-35, doi.org/ 10.1111/j.1468-2419.2007.00293.x.

[10] Garavan, T.N. and McGuire, D. (2010). Human Resource Development and Society: Human Resource Development's Role in Embedding Corporate Social Responsibility, Sustainability, and Ethics in Organizations. Advances in Developing Human Resources, vol. 12, issue 5, pp. 487-507, doi.org /10.1177/1523422310394757. 
[11] Garavan, T.N., et al. (2010). Conceptualizing the Behavioral Barriers to CSR and CS in Organizations: A Typology of HRD Interventions. Advances in Developing Human Resources, vol. 12, issue 5, pp. 587-613, doi.org/10.1177/1523422310394779.

[12] Gond, J.P., et al. (2011). The Human Resource Contribution to Responsible Leadership: An Exploration of the CSR-HR Interface. Journal of Business Ethics, vol. 98, issue 1, pp. 115-132, doi.org/10.1007/s10551-011-1028-1.

[13] Hasibuan, M. (2006). Manajemen Sumber Daya Manusia. Jakarta: Bumi Aksara.

[14] Jamali, D.R., El Dirani, A.M. and Harwood, I.A. (2015). Exploring Human Resource Management Roles in Corporate Social Responsibility: the CSR-HRM Co-Creation Model. Business Ethics a European Review, vol. 24 issue 2, pp. 125-143, doi.org/10.1111/beer.12085.

[15] Kartini, D. (2009). Corporate Social Responsibility: Transformasi Konsep Sustainability Management dan Implementasi di Indonesia. Bandung: Refika Aditama.

[16] Lako, A. (2011). Dekonstruksi CSR dan Reformasi Paradigma Bisnis \& Akuntansi. Jakarta: Erlangga.

[17] Lam, H. and Khare, A. (2010). HR's Crucial Role for Successful CSR. Journal of International Business Ethics, vol. 3, issue 2, pp. 3-15.

[18] Mangkunegara, A.P. (2013). Manajemen Sumber Daya Manusia Perusahaan. Bandung: Remaja Rosdakarya.

[19] Mathis, R.L. and Jackson, J.H. (2006). Human Resource Management: Manajemen Sumber Daya Manusia. Terjemahan Dian Angelia. Jakarta: Salemba Empat.

[20] Mirvis, P. (2012). Employee Engagement and CSR: Transactional, Relational, and Developmental Approach. California Management Review, vol. 54, issue 4, pp. 93117, doi. org/10.1525/cmr.2012.54.4.93.

[21] Notoatmodjo, S. (2009). Pengembangan Sumber Daya Manusia. Jakarta: Rineka Cipta.

[22] Rivai, V. (2009). Manajemen Sumber Daya Manusia Untuk Perusahaan Dari Teori ke Praktik. Jakarta: Raja Grafindo Persada.

[23] Sarvaiya, H. (2014). The Relationship between CSR and HRM: A Study of Large New Zealand Organisations. Retrieved from https://mro.massey.ac.nz/bitstream/handle/ 10179/6224/02_whole.pdf.

[24] Sarvaiya, H., Eweje, G. and Arrowsmith, J. (2016). The Roles of HRM in CSR: Strategic Partnership or Operational Support. Journal of Business Ethics, vol. 1, issue 1, pp. 1-13, doi.org/10.1007/s10551-016-3402-5. 
[25] SHRM. (2007). Corporate Social Responsibility: United States, Australia, India, China, Canada, Mexico, and Brazil. Retrieved from https://www.shrm.org/hr-today/trendsand-forecasting/research-and-surveys/documents/2007.

[26] Solihin, I. (2009). Corporate Social Responsibility: From Charity to Sustainability. Jakarta: Penerbit Salemba Empat.

[27] Stefano, D.F., Bagdadli, S. and Camuffo, A. (2018). The HR Role in Corporate Social Responsibility and Sustainability: A Boundary-Shifting Literature Review. Human Resource Management, vol. 57, issue 2, pp. 549-566, doi.org /10.1002/hrm.21870.

[28] Strandberg, C. (2009). The Role of Human Resource Management in Corporate Social Responsibility. Retrieved from https://corostrandberg.com/wp-content/ uploads/2009/12/csr-hr-management.pdf.

[29] Sugiyono. (2017). Metode Penelitian Kuantitatif, Kualitatif, dan R\&D. Bandung: Alfabeta.

[30] Susanto, A.B. (2009). Reputation-Driven Corporate Social Responsibility: Pendekatan Strategic Management dalam CSR. Jakarta: Penerbit Erlangga.

[31] Undang-Undang Republik Indonesia Nomor 25 Tahun 2007 tentang Perseroan Terbatas. Retrieved from http://www.hukumonline.com/pusatdata/detail/26608/ node/27/uu-no-25-tahun-2007-penanaman-modal.

[32] Undang-Undang Republik Indonesia Nomor 40 Tahun 2007 tentang Perseroan Terbatas. Retrieved from http://www.hukumonline.com/pusatdata/detail/26940/ node/70/undangundang-nomor-40-tahun-2007.

[33] Welford, R. (2005). Corporate Social Responsibility in Europe, North America, and Asia. Journal of Corporate Citizenship, vol. 17, pp. 33-52, doi.org/10.9774/GLEAF.4700.2005.sp.00007.

[34] Yang, N., Colvin, C. and Wong, Y. (2013). Navigating Corporate Social Responsibility Components and Strategic Options: The IHR Perspective. Academy of Strategic Management Journal, vol. 12, issue 1, pp. 39-58. 